\title{
SMART TECHNOLOGIES AND REFLECTIONS ON LOCAL PUBLIC ISSUES IN TURKEY: A REVIEW OF METROPOLITAN MUNICIPALITIES
}

\author{
Dr. Levent MEMiş*
}

\begin{abstract}
In this research, Internet of Things (IOT) and sensors which is characterized as "smart technologies" and the big data which substantially occurs based on these technologies have been discussed in terms of local governments. The technologies mentioned differ based on the space where they are used and, in this context, bring innovations to the table for local services such as transportation, security, waste, and infrastructure. On the other hand, the big data that emerge by means of smart technologies strengthens the predictability in decisions by decreasing the lapses. In this respect, it becomes possible to make more accurate decisions in terms of local governments. However, in order for a slew of negative occurrences to not be experienced in the process of obtaining and using data, it is important to show care to some matters (like data privacy and security). The reflection of new technological developments and big data which is expressed within this context, on Turkish local governments "how" and "how much" had been examined on metropolitan municipalities. In obtaining data, strategic plans and annual activities reports of the metropolitan municipalities were used primarily. Also, in order to determine metropolitan municipalities' implementations on this subject; related municipalities' web pages, academic researches and related news by means of search engines were benefited from. In an examination aimed at strategic plans of metropolitan municipalities, it is determined that space is given to the concept of "smart" without giving room to concepts like "IoT", "sensors/detectors", and "big data" in detail, more on the topic of "transportation". In this context, concepts such as smart signalization, smart stop, smart intersection, and smart ticket are brought to the agenda with regard to transportation. Conversely, when the applications that emerge are studied, it is seen that the topic of transportation takes a priority rank so as to complete the points that stand out in the strategic plan. Following transportations; water, energy and meteorological implementations are come to the forefront.
\end{abstract}

Keywords: IoT, Sensors, Big Data, Metropolitan Municipality, Turkey

ÖZ

Bu araştırmada, "akıllı teknolojiler" olarak nitelendirilen nesnelerin interneti (Internet of Things, $10 T$ ), sensörler ve büyük oranda bu teknolojilere bağlı olarak ortaya çıkan büyük veri, yerel yönetimler bağlamında ele alınmıştır. Adı geçen teknolojiler kullanılığı alana göre farkııık göstermekte ve bu bağlamda ulaşım, güvenlik, atık, altyapı gibi yerel hizmetler için de yenilikleri gündeme getirmektedir. Diğer taraftan akıllı teknolojiler aracılığıyla ortaya çıkan büyük veri, kararlardaki yanılmaları azaltarak öngörülebilirliği güçlendirmektedir. Bu sayede yerel yönetimler açısından daha doğru kararlar vermek mümkün hale gelmektedir. Fakat verilerin elde edilme ve kullanılma sürecinde birtakım olumsuzlukların yaşanmaması için bazı hususlara (verilerin gizliliği ve güvenliği gibi) özen gösterilmesi önem arz etmektedir. Bu kapsamda ifade edilen yeni teknolojik gelişmelerin ve büyük verinin, Türkiye'nin yerel yönetimlerine "nasıl" ve "ne derece" yansıdığı, büyükşehir belediyeleri üzerinden incelenmiştir. Verilerin elde edilmesinde, öncelikle büyükşehir belediyelerinin stratejik planları ve faaliyet raporlarından yararlanılmıştır. Ayrıca büyükşehir belediyelerinin bu konudaki uygulamalarını tespit etmek adına; ilgili belediyelerin web sayfalarından, akademik çalışmalardan, arama motorları aracılığıyla ilgili haberlerden yararlanılmıştır. Büyükşehir belediyelerinin stratejik planlarına yönelik incelemede, daha çok "ulaşım" konusu bağlamında, detayda "IoT", sensörler/algılayıcılar" ve "büyük veri" gibi kavramlara yer vermeden, "akıllı" kavramına yer verildiği tespit edilmektedir. Bu bağlamda ulaşımla ilgili akıllı sinyalizasyon, akıllı durak, akıllı kavşak, akıllı bilet gibi kavramlar gündeme getirilmektedir. Diğer taraftan ortaya çıkan uygulamalar incelendiğinde de, stratejik planda öne

\footnotetext{
- Giresun University, Faculty of Economics and Administrative Sciences, Department of Political Science and Public Administration, Giresun, Turkey., ORCID NO: 0000-0002-5438-691X
} 


\section{Dr. Levent MEMiş}

çıkan noktaları tamamlayacak şekilde, ulaşım konusunun öncelikli sırayı aldığı görülmektedir. Ulaşımı takiben; su, enerji ve meteorolojik uygulamalar öne çıkmaktadır.

Anahtar Kelimeler: ІІT, Sensörler, Büyük Veri, Büyükşehir Belediyesi, Türkiye

\section{Introduction}

Developments in science and technology oblige a specific transformation at the individual and organizational level. Public organizations are also inevitably exposed to this transformation, along with other political, social and economic variables. In the last 30 years time period, the most important technology that affects organizations, both internal organization, and functioning, as well as work carried out with external target groups, is the internet. Internet and internet-driven applications, while bringing some criticism to the agenda, are effective in participating and cooperating with decisions on public policy from one side (Perez, Bolivar and Hernandez, 2012; Gardini et al., 2012 ; Veljkovic, Bogdanovic-Dinic and Stoimenov, 2012; Hansen-Flaschen and Parker, 2012; Perlman, 2012; Deloitte, 2008b; Dixon, 2010; Omar, Stockdale and Scheepers, 2014), on the other hand it is effective at the operational level and in the presentation of services (Khan, Swarm and Lee, 2014; Tapscott, Williams and Herman, 2008; Perlman, 2012; Atari, Stewart-Weeks and McCalla, 2011).

Today, the internet has gained a new dimension by linking with different objects, apart from its use depending on certain vehicles (PC and mobile phone). Integrating different objects and the internet into one is the same as the concept loT. Another technology that complement the IoT is the sensors (Chen, Mao and Liu, 2014). The things and spaces that loT and sensors technologies correspond to are defined by the concept of "smart". Smart technologies facilitate the production and consumption of goods and services from one point of view, and in other respects provide possibilities for making things meaningful by making the data available, which can not be measured, stored, analyzed and shared in advance. The multiple (big) data obtained is the most important tool for making the right decisions in the organizational plane, maximizing the benefits that are generated by reducing inputs and realizing an efficient and efficient management process. When considered in terms of the public sector, the various data possessed have the potential to contribute to a wide area such as health of safety, efficient and efficient management of transportation waste, creation of certain scales.

Study's fundamental aim is, in the frame of what is expressed, to examine the reflection of the occurred smart technologies (IoT and sensors) and (big) data on Turkish local governments "how" and "how much" and develop suggestions in the frame of obtained findings. Within the scope of determined aim, the answers of the following questions are searched: 1 . How does smart technologies and the obtained big data have function in terms of local public affairs? 2. What is the place of smart technologies and big data in determination of local public policies and effective and efficient presentation of services in Turkey?

Depending on the designated purpose, the research consists of two parts. In the first part, theoretical level focuses on smart technologies from the perspective of public administration. In addition, in this section, it is focused on what it means for the increasing amount of data, from the point of view of the public administration, is from 
the smart technologies. In the second part of the research, an examination is carried out metropolitan municipalities in Turkey on the basis of the qualitative content analysis method. In this context, Turkey's metropolitan municipalities are examined in (30 pieces) sample; strategy and application dimensions, reflection of smart technologies in urban area. In obtaining the data; benefit from annual activity reports of the respective municipalities, strategic plans, academic publications, other reports prepared by the municipalities, web pages of the municipalities and search engines.

\section{IoT, Sensors and Local Government}

When the historical process is considered, it seems that technology as an important variable necessitates the transformation of individual and organizational life (Basalla, 2013). The technological developments that have taken place change the habits of living individuals and the ways in which organizations do business, leading society to gain new dimensions. The history of technology provides us with evidence of the situation being expressed. In this context in the 21 st century is underlined that two important developments affect the world. The first of these is the urbanization of the world population; secondly, thanks to internet technology, it is the emergence of connections between people and themselves, and at the level of objects (Scholl, 2016). When addressed at the organizational level, the Internet in the first place facilitated the operational communication between employees and managers within an organization; outside the organization, the interested parties offered the opportunity to benefit from faster services. But today, the internet has gained a new dimension through links established with objects. This emerging new situation is conceptualized as "IoT". Another technological development that comes to the end of the day to complement the loT is that the sensors are spreading in different shapes (Chen, Mao and Liu, 2014: 177).

IoT with living developments is said to be the third generation of the development of Internet technology. The first phase of the Internet is the establishment of links through fixed means. The second phase is where the internet meets mobile technology. In the third phase, the Internet meets with various objects (Deloitte, 2015a: 44). As of the end of 2016, the number of connected objects expected to be used worldwide is 6.4 billion, and the number of new objects provided each day is known as 5.5 million (Deloitte, 2016: 35 as cited in Garner 2015).

These developments reverberate favorable to public organizations in two respects. First, the internet facilitates the services offered by becoming more connected with more objects. Secondly, more acquire data through the mentioned technologies. These two technological developments and their data becoming important together make the objects or the field that these technologies correspond to, become "smart". Here, smart is used to describe sensors based devices (Stimmel, 2016: 6). The loT and sensors are the technological elements that complement one another. The smart objects that come up with the support of these technologies need to be contained in itself the sensor/sensors that interact with the physical world, a small microprocessor that processes the data, a communication device for transmitting the processed data to the relevant device and a power supply for supplying energy 


\section{Dr. Levent MEMiş}

(Vasseur and Dunkels, 2010: 3). It should be noted that these technological developments reflect a different situation that will include the smart concept ICT, together with the prior information and communication technologies that emerge (Scholl, 2016: ix; Anthopoulos et. al., 2016: 77). According to the field where Smart word is used, (Albino, Berardi and Dangelico, 2015) in different sectors finds (Thorne and Griffiths 2014: 91) in different formats.

Sensors responding to various situations, such as sound, light, heat, weight, mobility with certain algorithmic properties, measure the physical qualities or signals in an environment (Stimmel, 2016: 8-9), and the resulting data degrade (the place of a person or object, such as the temperature of the air) to meaningful figures. Sensors, for example; the vibration of buildings, bridges and other infrastructural components, and the state of the material can perform structural health analysis, and information about the repair can be transmitted. It is possible to take proactive measures at this point. Again, noise pollution, traffic congestion monitoring, calculation of pedestrian intensity, knowing whether there is an empty parking area, giving energy according to the illumination required by the street, the collection of waste according to occupancy rates, etc., sensors and internet networks offer significant contributions (Rifkin, 2015: 21; Mayer-Schönberger and Cukier, 2013: 66).

In the context of the stated ones, the urban area is managed; smart energy and smart networks for energy conservation and cost reduction; smart buildings in order to reduce energy consumption; smart water to reduce water loss; smart public services for the delivery of fast, efficient, more productive and economic public services; smart lighting for energy efficiency; smart illumination for energy efficiency; smart transport to reduce travel time and traffic intensity; for smart waste management to improve cleanliness and optimization, and more control of energy use and accurate billing, smartmeter applications are at the forefront (Novotny, Kuchta and Kadlec, 2014: 3).

\section{Big Data in Local Government}

The outstanding/gigantic data obtained from different sources (such as multi media, social media, IoT) by the contribution of new technological possibilities that are developed, are described as "big data" (Chen, Mao and Liu, 2014: 174). The concept of big data is used as an umbrella term, reflecting a wide variety of data (Mergel, Rothemeyer and Isett, 2016: 929). It should be noted that besides internet and sensor technology, other tools also contribute to the emergence of big data. Especially with the internet-based technological developments such as search engines, social networks, and the mass of data emerging from these sources, big data has begun to occupy the agenda (Chen, Mao and Liu, 2014: 171). Along with living improvements, big data at the national and international levels have started to be handled by linking with public affairs (World Economic Forum, 2012; Schwab, 2017: 87). There is also an international literature with different sizes (Tomar, et. al., 2016; Lavertu, 2016; Kim, Trimi and Chung, 2014; Pirog, 2014; Anthopoulos, 2017), in which there is a gradual increase in public awareness of big data.

The Big data allows to obtain all the data of a situation. At this point, more accurate decisions become possible by reducing the margin of error (Mayer- 
Schönberger and Cukier, 2013: 15). These developments together with the big data (Chen, Mao and Liu, 2014: 174), which has become one of the most important production factors, are characterized by different disciplines (such as management, public policy, political science, information and communication technology management) in different forms, with some characteristic features of (Mergel, Rothemeyer and Isett, 2016: 929). These features also come out in different researchers, in different forms, (Tomar, et al., 2016: 8; Desouza and Jacob, 2017: 1047) together with the following points in the foreground.

- Velocity: The emergence of new data in a very short period of time in the life and work dynamics.

- Volume: Increase in the volume of data generated from the macro level to personal data.

- $\quad$ Variety: The emergence of activities and thoughts by the method of sound, write and images.

- $\quad$ Complexity: The existence of different types of data from a wide variety of sources, and inter-data relationships

- Veracity: The authenticity of the source of the data is correct and complete.

- $\quad$ Machine learning: are automatically defined the big data obtained through powerful analysis programs developed.

- Digital Footprint: An important part of big data is the recording of interactions through mechanisms.

Big data (Deloitte, 2015b: 2) with the opportunities that create a lot of value, benefits us to understand the present and future risks and to organize our movements accordingly (Mayer-Schönberger and Cukier, 2013: 170). In this context, the public sector has the opportunity to uncover potential benefits "with big data", which is achieved by different methods in various fields. Big data in terms of public works; it is emerging through interactions through tools such as social media, automatically from sensors, and through intra-organizational operational activities (Mergel, Rothemeyer and Isett, 2016: 931). What is new to public organizations today, big data is on the agenda compared to before and big data has the potential to provide more benefits. However, for today, there is no common situation for public organizations to use big data (Munne, 2016: 196), there is a common interest in big data in the various policy documents prepared (Desouza and Jacob, 2017: 1044) ${ }^{1}$. Undoubtedly with the development of awareness and technical infrastructure, big data will produce results in specific areas, beyond the average values achieved today (Mergel, Rothemeyer and Isett, 2016: 931). In the context of statements, the benefits/opportunities that the big data will provide to the public sector are as follows: (Munne, 2016: 195-196; Desouza

\footnotetext{
1 The similar situation can be observed when looking at the policy documents which are prepared and current in Turkey [National Science and Technology Policies 2003-2023 Strategy Document, Energy Efficiency Strategy Document (2012-2023), Tenth Progress Plan (20142018), Information Society and Action Plan (2015-2018), National E-State Strategy and Action Plan (2016-2019) and National Smart Transportation Systems Strategy Document (2014-2023) and Its Annex Action Plan (2014-2016)].
} 


\section{Dr. Levent MEMiş}

and Jacob, 2017: 1044; Höchtl, Parycek and Schöllhammer, 2016: 155-156; Chen, Mao and Liu, 2014: 171):

- $\quad$ By making the big data clear, "open state" emerges, providing clearness and trust between the citizen and the state.

- It contributes to the improvement of democratic processes and to the strengthening of public sector outputs,

- In the process of generating citizenship-oriented services, it helps to policy makers,

- $\quad$ The planning and the results obtained improve the quality,

- It contributes to the discovery of unseen new values,

- The personalization of the services offered and thus increases the productivity, effectiveness and citizen satisfaction,

- With the correlation of data from many sources, more accurate financial estimations can be made,

- It increases the quality of life and security of citizens,

- A more defensible position is obtained against the cyber attack.

On the other hand, besides the potential benefit of the big data; most of the time when the data is obtained without permission from the producer, some difficulties/worries come to mind about the legitimacy, security, confidentiality of personal data (Höchtl, Parycek and Schöllhammer, 2016: 156). As the data are often obtained without authorization from the manufacturer, personal data, such as legitimacy, security, privacy, some problems come to the fore (Choenni et al., 2016: 354; Rifkin, 2015: 84; Deloitte, 2015a: 25). In fact, these developments come to the fore from again of George Orwell's book "1984" (Mayer-Schönberger and Cukier, 2013: 159). It is also underlined that some applications for the protection of personal data are used at [personal warning and consent, waiver and anonymization (collection of some data without matching personal information)], and that they are not very successful at the point reached (Mayer-Schönberger and Cukier, 2013: 161-163). Certain rules and ethical principles need to be developed to reduce the anxieties about the breach of personal data (Deloitte, 2016: 25).

\section{Purpose, Importance, Scope and Limitations of the Research}

Researches aim is, to examine the reflection of the occurred smart technologies (internet of things and sensors) and big data on Turkish local governments "how" and "how much" and develop suggestions in the frame of obtained findings. Within the scope of determined aim, the answers of the following questions are searched: 1 . How does smart technologies and the obtained big data have function in terms of local public affairs? 2. What is the place of smart technologies and big data in determination of local public policies and effective and efficient presentation of services in Turkey?

When the relevant literature is examined, it is understood that there is a lot of interest in terms of public administration towards development such as loT, sensors, big data at both the practical level and the theoretical level. With the increase in 
activities $^{2}$ focused on smart technologies, it is understood from the literature view that in the context of public administration discipline, there is a very limited (Varol, 2017) interest covering new technologies such as loT, sensors, big data in Turkey. This state of affairs reveals the importance of working.

The scope of study is metropolitan municipalities in Turkey. Metropolitan municipalities are important in terms of the variety of services they have and the population they have in terms of seeing the application of new technologies. It is also known that the density of the population in the urban area has increased and there is a positive relationship between the application of smart technologies as a solution to the problems (Manville, vd., 2014: 37). There are 30 metropolitan municipalities in Turkey. Metropolitan municipalities and their population (2016) are shown in Table 1 below. Another point from the point of view of the scope is that, as new technologies in the work come into the agenda; "loT", "sensors" and "big data" have been taken into consideration. Apart from these; classical technological elements such as network systems that facilitate internal organization of units, information systems within the scope of various services, e-municipality, mobile municipality are excluded from the scope of the study.

Table 1: Metropolitan Municipalities of Turkey

\begin{tabular}{c|c|c|c}
$\begin{array}{c}\text { Metropolitan } \\
\text { Municipalities }\end{array}$ & Population & $\begin{array}{c}\text { Metropolita } \\
\mathbf{n} \text { Municipalities }\end{array}$ & Population \\
\hline Adana & 2.201 .670 & Kayseri & 1.358 .980 \\
\hline Ankara & 5.346 .518 & Kocaeli & 1.830 .772 \\
\hline Antalya & 2.328 .555 & Konya & 2.161 .303 \\
\hline Aydın & 1.068 .260 & Malatya & 781.305 \\
\hline Balıkesir & 1.196 .176 & Manisa & 1.396 .945 \\
\hline Bursa & 2.901 .396 & Mersin & 1.773 .852 \\
\hline Denizli & 1.005 .687 & Mardin & 796.237 \\
\hline Diyarbakır & 1.673 .119 & Muğla & 923.773 \\
\hline Erzurum & 762.021 & Ordu & 750.588 \\
\hline Eskişehir & 844.842 & Sakarya & 976.948 \\
\hline Gaziantep & 1.974 .244 & Samsun & 1.295 .927 \\
\hline Hatay & 1.555 .165 & Şanlıurfa & 1.940 .627 \\
\hline İstanbul & 14.804 .116 & Tekirdağ & 972.875 \\
\hline İzmir & 4.223 .545 & Trabzon & 779.379
\end{tabular}

2 Smart Municipal Summit, May 2015 and November 2016/Istanbul; IoT and Ciber Safety, October 2016/Ankara; 4th International Istanbul Smart Networks and Cities Congress and Fair, April 2016/istanbul; 9. Smart Cities Congress, November 2015/istanbul; 8nd Smart Municipal Summit, November 2015/Bursa; 2nd International Intelligent Cities Conference, May 2016/Ankara; Big Data Analysis and Security Public Workshop, February 2016/Ankara. 


\section{Dr. Levent MEMiş}

\begin{tabular}{l|l|l|l}
$\underset{\text { Kahramanma }}{\text { raş }}$ & 1.112 .634 & Van & 1.100 .190
\end{tabular}

Source: Turkish Statistical Institute, Basic Statistics-Population and Demography, http://www.tuik.gov.tr/UstMenu.do?metod=temelist (Accessed 10 October 2017).

The basic limitation of the research comes from its dependence on text analysis within the scope of the qualitative content analysis method. Due to time and budget constraints, besides text analysis, other qualitative research methods such as interviewing that applied in similar researchs (Alawadhi, et al. 2011) was not benefited.

\section{Research Method}

In the study, content analysis method is mainly used which is a qualitative research method that is based on document analysis. Content analysis is a research method which is used to make an inference that is repeatable and valid from texts or documents or publishing such as videos, pictures and photographs (Krippendorff, 2004: 18). The basic process in content analysis is to bring together the similar data in the frame of certain concepts and themes and to interpret them with organizing in a way that readers can understand (Yıldırım and Şimşek, 2008: 227). Content analysis is applied to Strategic Plans ${ }^{3}$ and 2016 annual activity reports ${ }^{4}$ of the metropolitan municipalities. In texts, first of all, the words "smart", "internet", "loT", "sensor", "detector", "technology", "data" and "big data" were tried to determine via the opportunity of the program which provides us to read the documents in computer environment. After that, with looking at the contexts of the related words used, it is focused on strategies and activities. Also, if the examined documents categorized as structurally, text was searched from beginning to the end and it is tried to determine the implementations of these concepts related to subject. In the executed examination, if the concept "smart" is used and does not include the technologies such as executed implementation sensors and internet of things (such as smart bicycle, smart education ${ }^{5}$ ), they are excluded from the scope of the research.

On the other hand, related news and documents in municipalities' webpage are used as data acquiring tool. Also, the related subjects follow-up was made with utilizing from search engine.

\section{Research Findings}

\subsection{Aims and Strategies of the Metropolitan Municipalities Towards Smart Technologies and Big Data}

When looking at the point of view of today, the services, which are presented on public level, were more left to local governments and a situation, which localization comes to prominence in this respect, is happening in the world. For this reason,

\footnotetext{
${ }^{3}$ Access to 30 Metropolitan Municipalities' strategic plan is provided.

${ }^{4}$ The examination of the activity reports on the determined method is executed in between the dates 01-10 October 2017. In the specified dates, access to Van and Ordu Metropolitan Municipalities' Activity Report was not provided.

${ }^{5}$ İstanbul Metropolitan Municipality: www.akilliegitim.org/
} 
depending on the variety of services that presented, technological solutions are of more concern to local and the compatibility of the cities towards technological development is important. In the Table 2 below, there is aims and strategies of the metropolitan municipalities towards smart technologies and big data. Strategic planning is equal to be ready changing environmental conditions of an organization and the effort of determining its direction in long run. In this context, Turkey's strategic planning in the structure of public administration with a law enacted in 2003 (5018 numbered Public Finance Management and Control Law) has been added to agenda. This law also regulates preparation of annual activity reports. In the Metropolitan Municipality Law, that inured in 2004, there are arrangements towards preparation of municipalities' strategic plan and activity reports (Songör, 2011: 7).

Table 2: Aims and Strategies of the Metropolitan Municipalities towards Smart Technologies and Big Data

\begin{tabular}{|c|c|}
\hline $\begin{array}{l}\text { Metropo } \\
\text { litan } \\
\text { Municipalities }\end{array}$ & Aims and Strategies towards Smart City \\
\hline Adana & $\begin{array}{l}\text { (In intersections) Extensification of smart signalization systems, } \\
\text { extensification of Traffic Electronic Supervision System (TEDES), the } \\
\text { execution of the "smart touch project" for disabled people to use sidewalks } \\
\text { easily and extensification of smart stops. }\end{array}$ \\
\hline Ankara & No strategy is detected related to smart city. \\
\hline Antalya & $\begin{array}{l}\text { Strengthen the transportation infrastructure and smart } \\
\text { transportation systems. }\end{array}$ \\
\hline Aydın & $\begin{array}{l}\text { Promote public transportation with developing new technologies } \\
\text { and create databank for disadvantaged groups. }\end{array}$ \\
\hline Balıkesi & $\begin{array}{l}\text { Creation of databank towards rural area and lands and integration } \\
\text { it to the city information system and execution of signalization project. }\end{array}$ \\
\hline Bursa & $\begin{array}{l}\text { Establish electronic traffic system, making projects with following } \\
\text { innovations in information technologies and improve equipment } \\
\text { infrastructure. }\end{array}$ \\
\hline Denizli & No strategy is detected related to smart city. \\
\hline Diyarba & $\begin{array}{l}\text { Make actual the smart stop implementation and generalize the } \\
\text { traffic signalization system. }\end{array}$ \\
\hline Erzuru & $\begin{array}{l}\text { Develop and generalize smart traffic systems, make smart stops } \\
\text { and resting cabins, establish automation system in fuel stations and } \\
\text { provide simultaneous traceablity. }\end{array}$ \\
\hline Eskişeh & Extensification of network traffic infrastructure smart intersections, \\
\hline Gaziant & No strategy is detected related to smart city. \\
\hline Hatay & No strategy is detected related to smart city. \\
\hline İstanbul & $\begin{array}{l}\text { Generalize smart transportation systems as to include all public } \\
\text { transportation vehicles. }\end{array}$ \\
\hline
\end{tabular}




\begin{tabular}{|c|c|}
\hline İzmir & $\begin{array}{l}\text { Carry out the implementations of smart map based on GSM, data } \\
\text { sharing services, smart traffic management system and smart stops. }\end{array}$ \\
\hline $\begin{array}{l}\text { Kahram } \\
\text { anmaraş }\end{array}$ & $\begin{array}{l}\text { Establish and generalize kiosk and smart cash point systems, } \\
\text { create smart intersection system and move to smart stop system. }\end{array}$ \\
\hline Kayseri & $\begin{array}{l}\text { Provide the development and keep up-to-date of system of } \\
\text { electronic fee collection system according to technological developments, } \\
\text { provide transition to smart stop system, generalize the usage of smart } \\
\text { card in public transportation, create databank for license (business), } \\
\text { provide instant data collection with the support of } 3 G \text { modem of vehicles } \\
\text { (municipality), create database of disabled and provide topicality of } \\
\text { cadastres data with getting them with WMS (Web Map Service). }\end{array}$ \\
\hline Kocaeli & $\begin{array}{l}\text { Create signalize intersection and smart transportation systems and } \\
\text { ground databank. }\end{array}$ \\
\hline Konya & $\begin{array}{l}\text { Establish EDS, smart stops and meteorological sensor, create a } \\
\text { center that all of the data belong to municipal work will gathered and } \\
\text { managed, create and keep up-to-date disabled database, create } \\
\text { agriculture and animal husbandry database. }\end{array}$ \\
\hline Malatya & $\begin{array}{l}\text { Prepare smart city master plan towards the implementation of } \\
\text { smart city and make work related to open data. }\end{array}$ \\
\hline Manisa & No strategy is detected related to smart city. \\
\hline Mardin & $\begin{array}{l}\text { Establish central control system which includes smart } \\
\text { transportation systems. }\end{array}$ \\
\hline Mersin & $\begin{array}{l}\text { Making actual of smart stop implementations, transformation of } \\
\text { intersections to smart signalization, taking of the smart talk seat, }\end{array}$ \\
\hline Muğla & $\begin{array}{l}\text { Implement signalization projects related to intersections and } \\
\text { crosswalks. }\end{array}$ \\
\hline Ordu & No strategy is detected related to smart city. \\
\hline Sakarya & $\begin{array}{l}\text { Carry out the implementations of smart bus, prepare stop database } \\
\text { and develop dynamic intersection implementation with signalization } \\
\text { system. }\end{array}$ \\
\hline Samsun & Generalize traffic signalization system. \\
\hline Şanlıurf & $\begin{array}{l}\text { Establish smart ticket top up machine and create smart } \\
\text { intersections. }\end{array}$ \\
\hline Tekirda & $\begin{array}{l}\text { Move to implementations of smart ticket, smart stop and smart } \\
\text { intersection, implement smart transportation systems and TEDES and } \\
\text { create database for the needy people. }\end{array}$ \\
\hline Trabzon & Carry out the implementation of smart intersection. \\
\hline Van & $\begin{array}{l}\text { Move to the implementation of smart stop, start the works of smart } \\
\text { intersection and move to Electronic Supervision System (EDS). }\end{array}$ \\
\hline
\end{tabular}

The strategic plans of metropolitan municipalities cover the years 2015-2019 except the Metropolitan Municipalities of Kayseri (2016-2020) and Diyarbakır (20172021). When the strategic aims and targets, which are obtained as of the scope of the 
study, examined, it is observed that "transportation" head piece has come to the fore substantially. On the other hand, concepts such as "internet of things", "sensors/detectors" and "big data" are not included in strategic plans, and it is now determined that it is now determined that there is a intension towards classical information and communication technologies. It is seen that data is included more as "small data" concept.

\subsection{IoT, Sensors and Big Data in the Local Level Applications}

As a result of the examination of annual activity reports of metropolitan municipalities, in Table 3 there are the findings include loT, sensors and big data.

Table 3: Smart City Practices of Metropolitan Municipalities in Turkey

\begin{tabular}{|c|c|c|}
\hline $\begin{array}{l}\text { Metropolitan } \\
\text { Municipalitie } \\
\text { s }\end{array}$ & $\begin{array}{l}\text { Smart City } \\
\text { Applications }\end{array}$ & Descriptions \\
\hline Adana & $\begin{array}{cc}\text { Smart Traffic Systems } \\
\bullet \quad \text { Smart } \\
\text { Signalization } & \text { System } \\
\bullet & \text { TEDES }\end{array}$ & $\begin{array}{l}\text { It is stated that the works started } \\
\text { in } 2013 \text { are continuing in order to } \\
\text { contribute to the resolution of traffic } \\
\text { problems. }\end{array}$ \\
\hline Ankara & $\begin{array}{l}\text { Smart Stop } \\
\text { SCADA } \\
\text { Vehicle Tracking } \\
\text { System }\end{array}$ & $\begin{array}{l}\text { It is expressed in the activity } \\
\text { report that smart transportation systems } \\
\text { can be used effectively, but there is no } \\
\text { concrete application example. }\end{array}$ \\
\hline Antalya & $\begin{array}{l}\text { Electronic Fare } \\
\text { Collection and Vehicle } \\
\text { Tracking System with Smart } \\
\text { Card Technology } \\
\quad \text { Electronic Control } \\
\text { System } \\
\text { Smart Illumination } \\
\quad \text { Smart Irrigation } \\
\text { Systems } \\
\text { Drinking Water SCADA } \\
\text { System }\end{array}$ & $\begin{array}{l}\text { It is tried to make the public } \\
\text { transport more efficient by informing } \\
\text { passengers full-time information via } \\
\text { vehicle tracking system. In public spaces, } \\
\text { efforts are also being made to use } \\
\text { energy and water more efficiently. }\end{array}$ \\
\hline Aydın & Smart Stop & $\begin{array}{l}\text { It stands out as a concrete } \\
\text { application for new technologies, but it is } \\
\text { understood that it has not yet been } \\
\text { realized. }\end{array}$ \\
\hline Balıkesir & $\begin{array}{l}\text { Traffic Signalization } \\
\text { Smart Stop } \\
\text { Where is My Bus? } \\
\text { Smart Parking }\end{array}$ & $\begin{array}{l}\text { Although classic web-based } \\
\text { processes are now performed, it is the } \\
\text { only work that comes to light in the } \\
\text { context of new technologies. }\end{array}$ \\
\hline
\end{tabular}




\begin{tabular}{|c|c|c|}
\hline Bursa & $\begin{array}{l}\text { (Big) Data Center } \\
\text { Vehicle Tracking } \\
\text { Systems } \\
\text { Signalized intersections } \\
\text { Detector intersections } \\
\text { Elevator Tracking } \\
\text { System } \\
\text { Historical Sites } \\
\text { Illumination Tracking System }\end{array}$ & $\begin{array}{l}\text { A data center has been created } \\
\text { for the effective management of } \\
\text { emerging data stack. In addition to this, } \\
\text { the sensors are used to make the traffic } \\
\text { effective, besides these, plans have } \\
\text { been made to provide connectivity with } \\
\text { different objects. }\end{array}$ \\
\hline Denizli & $\begin{array}{l}\text { Traffic Management } \\
\text { System } \\
\text { SCADA System } \\
\text { Smart Globule Irrigation } \\
\text { System } \\
\text { Vehicle Tracking } \\
\text { System } \\
\text { Intersection } \\
\text { Signalization }\end{array}$ & $\begin{array}{l}\text { At the institutional level, intelligent } \\
\text { applications stand out in increasing the } \\
\text { efficiency of the vehicles, managing the } \\
\text { traffic intensity more effectively, and in } \\
\text { watering both drinking water and public } \\
\text { spaces. }\end{array}$ \\
\hline Diyarbakır & $\begin{array}{l}\text { Smart Intersection (15 } \\
\text { pieces) }\end{array}$ & $\begin{array}{l}\text { With this application; benefits } \\
\text { such as road efficiency, road safety, } \\
\text { emission reduction, increase in service } \\
\text { quality are expected. }\end{array}$ \\
\hline Erzurum & $\begin{array}{l}\text { Smart Stop } \\
\text { Intersection } \\
\text { Signalization }\end{array}$ & $\begin{array}{l}\text { The smart stops were specially } \\
\text { equipped with heat to respond to the } \\
\text { characteristics of the winter season. }\end{array}$ \\
\hline Eskişehir & $\begin{array}{l}\text { Network Traffic } \\
\text { Infrastructure Smart } \\
\text { lintersection (at } \\
\text { intersection 17) }\end{array}$ & $\begin{array}{l}\text { To make the waiting times in the } \\
\text { traffic signs more optimal, they have } \\
\text { been carry into effect. }\end{array}$ \\
\hline Gaziantep & $\begin{array}{l}\text { Smartmeter (water and } \\
\text { electricity) } \\
\text { Smart Stop } \\
\text { Vehicle Tracking } \\
\text { System } \\
\text { Smart Irrigation } \\
\text { Systems } \\
\text { Heat Control } \\
\text { Intersection } \\
\text { Signalization }\end{array}$ & $\begin{array}{l}\text { It is seen that with the } \\
\text { cooperation of the private sector, efforts } \\
\text { are being made to develop new } \\
\text { technologies for the city. Unlike other } \\
\text { applications, temperature control is } \\
\text { carried out in order to keep the heat at a } \\
\text { certain level in the zoo. }\end{array}$ \\
\hline Hatay & $\begin{array}{l}\text { Smart Stop } \\
\text { Traffic Signalization }\end{array}$ & ---- \\
\hline
\end{tabular}




\begin{tabular}{|c|c|c|}
\hline Istanbul & $\begin{array}{l}\text { Traffic Measurement } \\
\text { Systems ( } 900 \text { pieces in } \\
\text { different types) } \\
\quad \text { Icing Early Warning } \\
\text { Systems ( } 35 \text { pieces at different } \\
\text { points) } \\
\text { Electronic Control } \\
\text { Systems ( } 433 \text { pieces for } \\
\text { different purposes) } \\
\quad \text { Signalization Systems } \\
\text { (pedestrian and intersections } \\
\text { 2564) }\end{array}$ & $\begin{array}{l}\text { The data obtained through these } \\
\text { systems are gathered at a center and are } \\
\text { transferred instantaneously to the } \\
\text { drivers, contributing to making the traffic } \\
\text { safer and also providing efficiency to the } \\
\text { municipality in terms of road services. }\end{array}$ \\
\hline İzmir & $\begin{array}{l}\text { Full Adaptive Traffic } \\
\text { Management, Auditing and } \\
\text { Information System } \\
\text { Signalization System (30 } \\
\text { pieces) } \\
\quad \text { Central Traffic } \\
\text { Management System (44,21\% } \\
\text { realized) }\end{array}$ & $\begin{array}{l}\text { Through the transportation } \\
\text { services, new technological applications } \\
\text { come to the forefront. It is understood } \\
\text { that ( } 291 \text { at intersection9 is especially } \\
\text { focused on signalization systems. Except } \\
\text { this; Applications such as red light } \\
\text { infringement detection system, speed } \\
\text { corridor detection system, traffic } \\
\text { measurement system, parking } \\
\text { infringement system, smart stop are } \\
\text { performed. }\end{array}$ \\
\hline $\begin{array}{l}\text { Kahramanma } \\
\text { raş }\end{array}$ & $\begin{array}{c}\text { Smart Adaptive } \\
\text { Signalization System } \\
\text { Smart Stop } \\
\text { Smart Tracking (for } \\
\text { ages } 65 \text { and over) }\end{array}$ & $\begin{array}{l}\text { It is a system realized for } \\
\text { cooperation with other Metropolitan } \\
\text { Municipality in order to provide traffic } \\
\text { fluidity at an optimum level. }\end{array}$ \\
\hline Kayseri & $\begin{array}{l}\text { Smart Stop (QR } \\
\text { application) } \\
\text { Signalization } \\
\text { Applications } \\
\text { Smart Illumination (with } \\
\text { sensors) }\end{array}$ & $\begin{array}{l}\text { To make it easier for citizens to } \\
\text { take advantage of public transport } \\
\text { services, card application comes to the } \\
\text { forefront. Smart applications that provide } \\
\text { energy efficiency via QR coded stops } \\
\text { and sensors have been started. }\end{array}$ \\
\hline Kocaeli & $\begin{array}{l}\text { Smart Stop (e-komobil } \\
\text { application) } \\
\quad \text { Mobile Electronic } \\
\text { Control System (mobile } \\
\text { camera and sensors) } \\
\text { Traffic measurement } \\
\text { systems (road sensors) } \\
\quad \text { Drinking Water SCADA } \\
\text { (Supervisory Control And Data } \\
\text { Acquisition) System }\end{array}$ & $\begin{array}{l}\text { It is understood that the new } \\
\text { technological solutions developed are } \\
\text { transportation-oriented. In this context; it } \\
\text { has been determined that efforts have } \\
\text { been made to increase the efficiency of } \\
\text { waiting points, to ensure traffic safety } \\
\text { and ease. }\end{array}$ \\
\hline Konya & Smart Intersection & With Environmental Management \\
\hline
\end{tabular}




\begin{tabular}{|c|c|c|}
\hline & $\begin{array}{l}\text { Environmental } \\
\text { Management Information } \\
\text { System } \\
\text { Vehicle Tracking } \\
\text { System } \\
\quad \text { Smart Public } \\
\text { Transportation System }\end{array}$ & $\begin{array}{l}\text { Information System; monitoring of air } \\
\text { quality and noise pollution and follow-up } \\
\text { of wastes. With Intelligent Public } \\
\text { Transportation System; By means of the } \\
\text { developed application, it is possible to } \\
\text { utilize the stop and vehicle information to } \\
\text { the full-time citizens more efficiently than } \\
\text { the public transportation. }\end{array}$ \\
\hline Malatya & $\begin{array}{l}\text { Smart Intersection } \\
\text { Smart Pole }\end{array}$ & ---- \\
\hline Manisa & $\begin{array}{l}\text { Smart Stop } \\
\text { Intersection } \\
\text { Signalization }\end{array}$ & --- \\
\hline Mardin & ---- & $\begin{array}{l}\text { In the planning for the } \\
\text { development of intelligent transport } \\
\text { systems, no practical activity has been } \\
\text { identified. }\end{array}$ \\
\hline Mersin & $\begin{array}{c}\text { Smart Intersection } \\
\text { Smart Stop } \\
\text { Where is My Bus? } \\
\text { Intelligent Transition } \\
\text { Systems } \\
\text { Agricultural Forecasting } \\
\text { and Early Warning Systems }\end{array}$ & $\begin{array}{l}\text { Farmers are informed by making } \\
\text { necessary measurements thanks to the } \\
\text { Agricultural Forecasting and Early } \\
\text { Warning Systems developed to reduce } \\
\text { the agricultural damages caused by } \\
\text { meteorological risks. }\end{array}$ \\
\hline Muğla & $\begin{array}{l}\text { Smart Stop (7 pieces) } \\
\text { Geographic Data } \\
\text { Sharing Platform }\end{array}$ & $\begin{array}{l}\text { The Geographic Data Sharing } \\
\text { Platform is an incomplete project } \\
\text { developed for the efficient use of } \\
\text { geographic data by municipalities in the } \\
\text { metropolitan area and for the non- } \\
\text { recurrence. }\end{array}$ \\
\hline Ordu & $\begin{array}{l}\text { Traffic Electronic } \\
\text { Control System (TEDES) } \\
\text { Open-DAl (nearest } \\
\text { important places) }\end{array}$ & $\begin{array}{l}\text { The Open-DAl project, with } \\
\text { partners from different countries, is } \\
\text { supported by the European Commission } \\
\text { funding. With this project, the application } \\
\text { of "nearest important places" will be } \\
\text { passed on. }\end{array}$ \\
\hline Sakarya & \begin{tabular}{l}
\multicolumn{2}{c}{ Smart Tranportation } \\
System (SAKUS) \\
$\bullet \quad$ Smart \\
Intersections \\
$\qquad \quad$ Smart Parking \\
SCADA System
\end{tabular} & $\begin{array}{l}\text { It focuses on accelerating traffic } \\
\text { flow through various data obtained about } \\
\text { transportation. }\end{array}$ \\
\hline Samsun & Traffic Signalization & $\begin{array}{l}\text { In the upper scale, studies such } \\
\text { as "Samsun Smart City Maturity Analysis } \\
\text { and Road Map" are carried out and it is }\end{array}$ \\
\hline
\end{tabular}




\section{Dr. Levent MEMiş}

\begin{tabular}{|c|c|c|}
\hline & & $\begin{array}{l}\text { understood that some applications like } \\
\text { smart stop are planned. But there are } \\
\text { very limited applications. }\end{array}$ \\
\hline Şanlıurfa & Smart Intersection & ---- \\
\hline Tekirdağ & $\begin{array}{l}\text { Intersection } \\
\text { Signalization (Smart } \\
\text { Intersection) } \\
\quad \text { Vehicle Tracking } \\
\text { System }\end{array}$ & $\begin{array}{l}\text { In the strategic plan is the one } \\
\text { that applies in the current situation, } \\
\text { together with planning to implement } \\
\text { applications such as TEDES and smart } \\
\text { stop. }\end{array}$ \\
\hline Trabzon & $\begin{array}{l}\text { Smart Intersection } \\
\text { Vehicle Tracking } \\
\text { System }\end{array}$ & ---- \\
\hline Van & ---- & $\begin{array}{l}\text { In the strategic plan; smart stop, } \\
\text { smart intersection, the smart tracking } \\
\text { system is planned to be done. But he did } \\
\text { not go to practice. }\end{array}$ \\
\hline
\end{tabular}

When the findings in Table 2 are examined, it appears that smart technologies are reflected in service offerings of metropolitan municipalities outside of two municipalities. Especially, it is understood that applications that focus on the issue of transportation have gained more weight with different names. Following transportation; water, energy and meteorological applications come to the forefront. A similar situation can be seen in a survey of intelligent initiatives of cities across ten different cities and most of them are in the fields of environment, transportation, and energy (Ojo et al., 2015). But "open data" applications that important in some other cities (Melbourne, Hong Kong, London, Vienna, Seoul, vb.) were not detected (Anthopoulos, 2017b).

Applications that stand out in the context of transportation are:

6.2.1. Traffic Measuring Systems: These applications, which have been named differently and are combined under the heading of Traffic Measurement Systems, are utilized to transmit to the related parties collectively and momentarily at a data center related to traffic flow with the aid of sensors. Thanks to this data obtained, the traffic flow is better managed and the drivers are directed to different routes and also the data obtained helps to improve the transportation policies. It is known that their applications are in different forms. Especially reflected in practice in the metropolis like İstanbul, İzmir, Kocaeli, Antalya, Bursa where the population density is higher and the transportation problems are on the agenda.

6.2.2. Signalization Systems: It is seen that the signalization systems, which are basically sensors, are applied in different forms. When used in traffic lights, the signalization system provides traffic flow according to the intensity of the vehicles. Through the instantaneous data obtained through the sensors; waiting periods are brought to the optimum level, it is possible to increase the flow and prevent the loss of time. 


\section{Dr. Levent MEMiş}

6.2.3. Smart Stop: The smart stop, with its different applications, is an application to promote public transport and to better plan the travel plans of those who want to travel with these vehicles. What is important here is to realize the communication between the public transport, the stop and the passenger.

6.2.4. Vehicle Tracking Systems: This system enables remote monitoring and management of vehicles. It is expressed that the system works with the logic of transferring the devices attached to the vehicles to the server computers via GPS satellites and the data received from the sensors connected to the devices via GSM / GPRS. When the table is examined it is seen that municipalities commonly find this application.

6.2.5. Traffic Electronic Monitoring System (EMS): It is an application developed to detect the violations that occur in the traffic with the help of sensors and to reduce the violations in this way in order to ensure the safety of drivers and in the pedestrians. It is known that (Istanbul example: reverse direction, traffic light violation, parking violation) is applied in different forms according to necessity.

Applications identified in the context of water consumption are:

6.2.6. Smartmeter (SCADA): Thanks to this application, the channel systems providing water (such as drinking water, wastewater) fluidity, monitoring of valves and motors, determination of fault conditions, water levels and chemical components can be controlled remotely.

6.2.7. Smart Irrigation: In this system, which is developed for the active and efficient use of water in irrigation areas, the status of soil and air is sensed through sensors and irrigation operations are performed based on this data. In addition, this system can be controlled remotely. It is applied in the parks and garden areas of the municipalities.

Applications identified within the scope of energy and meteorology are:

6.2.8. Smart Illumination: Thanks to the sensors, efficient and efficient use of the energy used for lighting can be realized. Urban areas can be used for open space or street lighting, as well as for illuminating historic areas.

6.2.9. Temperature Control: This practice, found in a metropolitan municipality (Gaziantep), has emerged to facilitate the life of animals that are sensitive to heat in zoos.

6.2.10. Agricultural Forecasting and Early Warning Systems: With this application, which is supported by sensors, it is aimed to increase the productivity of farmers who are interested in agricultural production by reducing the risks caused by weather conditions.

The application of "Where is my bus?" for more effective use of public transport, the application of "Nearest major places" to better meet the needs of people in the location where they are located and the presence of "smart vehicle" systems for monitoring older people over 65 years of age are determined. 
When the findings are examined; Istanbul, Bursa, Denizli and Antalya Metropolitan Municipalities' new technologies and smart city studies covering big data stand out.

When the Istanbul Metropolitan Municipality's strategic plan (2015-2019) is examined, it is determined that there is no strong emphasis on new technologies directed to (IoT, cloud computing, sensors, etc.) and big data. However, one of the strategic objectives determined in the context of transportation services is expressed as "Expanding Smart Transportation Systems to Include All Public Transportation Vehicles" (82). Explanation of the specified target is as follows: "Establishment of smart transport and signaling systems to meet the needs and expectations of every segment of the society, to ensure disciplined and comfortable traffic flow of pedestrian and vehicle traffic, to take care of disadvantaged groups, and to ensure regular operation..." One of the important targets identified on the other side is Data Center (data center, backup center and common system infrastructure) (227).

When the activity report is examined, it is seen that new technological developments are transferred to practice in order to solve more traffic problems. On the other hand, it is stated that the data warehouse system has been established for the effective management of the data coming from the operational level and from the external sources, and subsystem studies for effective use of the data have been continued. The data obtained from the various information systems created are collected in a centralized (Traffic Control Center), traffic management is carried out, and transmitted to the drivers via the internet and mobile applications (IBB CepTrafik, IBB Navi). At the same time, it is understood that these data also contribute to the creation of public policies. It is also emphasized that the studies related to Data Center are continuing (51). All these efforts are carried out by the Istanbul Metropolitan Municipality "Istanbul Informatics and Smart City Technologies Inc. ".

It is understood that efforts towards intelligent urbanization in Istanbul in particular have intensified towards the last years. Within this scope, Smart City Internal Stakeholder Meeting (September 2016) has been realized and studies of IstanbulSmart City Living Lab are underway. The Data Center, with its strategic planner on the other side, has been operational in September 2017 under international standards (Uptime Institute Tier III). The central formation is based on the importance of big data, which is positioned as an integral part of development, productivity and sustainability. Along with the center; it is envisaged that the required data and the obtained data will be safely stored, and the efficiency and quality of services will increase.

It is understood that the Bursa Metropolitan Municipality has begun to give importance to its studies covering new technologies with "Smart Cities Road Map" announced in December 2016. When examining the applications implemented in this context, the different data generated at the operational level are managed through the separately created information systems (maintenance-repair, material management, purchase, shelter, etc.). Among the projects planned to be realized are; elevator tracking system and historical lighting system tracking project. It is also understood that smart cities have great importance to the data management that forms the heart of 


\section{Dr. Levent MEMiş}

them. At this point, necessary infrastructure systems have been established to safely store and process data.

It is known that the Antalya Metropolitan Municipality's history for smart city applications extends to 2015, but with the work program announced on August 2017, it is beginning to focus more on smart city studies. Although not included in the Antalya Metropolitan Municipality Strategic Plan, according to the information provided on the other platform, among the applications which are tried to be alive, applications such as "Panic button" application, intersection signalization, smart lighting, smart irrigation for fast follow up in the case of emergency in case of advanced persons are highlighted.

The Metropolitan Municipality of Denizli places importance on smart city studies and its own smart city applications in a separate section which is added to the corporate web page. This situation also reflects the importance given to the topic at the institutional level. When the information gave the examined, the efforts made for the smart city; is under the title transportation, water, information systems, environment and energy.

\section{Conclusions and Recommendations}

When we look roughly at the course of the life of people, it seems that technology plays a role very significant in the process finding "better". From the simple technological tools that emerged in the first place, it is understood that this advantage has been greatly influenced by today's advanced technologies. But in general, there is a paradoxical situation between technology and life, and more particularly between technology and city. That is, when technological developments bring human life to a better state by facilitating it, some problems are brought to the agenda. Technological developments are also being exploited to solve the problems created. The resulting cycle continues and the organizations/individuals continue their lives in this cycle. Public organizations are also shaped in this transformation.

In particular, the technological developments that have taken place with the Internet appear to be reflected in two important aspects: (IoT and sensors), public administration, facilitating the provision of services and obtaining more data. When objects are equipped with sensors and internet networks, big data stacks are emerging compared to the previous ones. When this data is well managed, it contributes significantly to the development of public policies. In other words, the big data that is owned by the public administration provides important contribution to the success criteria such as rationality, efficiency, efficiency, affordability, participation, quality, transparency, accountability, which is on the agenda. However, it should be noted that the technological developments that have been experienced; data privacy, protection, legitimacy, it is emphasized that some concerns and data standards, such as protection, bring with it difficulties.

In this research, it is discussed that the reflections of developing smart technologies on public organization. In this context, in the research, in particular of Turkey, the response of those who developed smart technology strategy and implementation at the local level to the metropolitan municipality "how" and "how much" reflected the examination is performed. In this context, it is seen that the 
"transportation" superstructure has come to the forefront in the examination conducted on strategic plans. However, it is determined that concepts like "loT", "sensors" and "big data" are not included.

Another part of the research is reflected in the applications of new smart technologies to local governments. In this context, the practices of 30 metropolitan municipalities in Turkey have been tried to be determined. In the review; especially those that focus on transportation, have gained more weight. Following transportation; water, energy and meteorological applications come to the forefront. The applications are as follows: Traffic Measuring Systems, Signalization Systems, Smart Stop, Vehicle Tracking Systems, Traffic Electronic Control Systems, Smart Counter, Smart Irrigation, Smart Illumination, Temperature Control, Agricultural Forecast and Early Warning Systems. Istanbul, Bursa, Denizli and Antalya smart city studies covering the new technologies and big data of the Metropolitan Municipalities stand out. Especially the "data center" which is in the effort to be established within the scope of Istanbul Metropolitan Municipality is an important step in terms of managing big data.

In the context of statements, in order to make better use of emerging technological opportunities, the following suggestions can be made, in particular in the context of local governments:

- $\quad$ First of all, how smart technologies are reflected to the urban area and how they are reflected, considering the unique conditions of each city,

- $\quad$ According to the findings of the analysis, the smart urban strategy and action plans covering the topics in the urban area in a holistic way [the importance of plans and strategies in cities that stand out with good smart practices (see Anthopoulos, 2017b: 131-133)],

- Co-operation with different stakeholders (university, private sector, NGOs, other public organizations) because establishment of necessary infrastructure and development of technologies (see Amsterdam and Genova examples, Dameri, 2014)

- In particular, efforts are being made to develop specific principles and standards for the confidentiality and security of acquired data (with a multilateral attitude),

- If you have user data; the information of this situation should be given to the user such as what purpose the obtained data will be used for and what kind of public utility will be used if it is used,

- $\quad$ Establishment of relevant topic-based formal platforms in order to create examples for other units by sharing experiences of different local government units,

- $\quad$ In the relevant legislation, the realization of the regulations that can meet the requirements of the new situation,

- It is considered important that local governments organize their organizational structure in the context of both technical and human resources in response to effective management of big data.

\section{REFERENCES}




\section{Dr. Levent MEMiş}

ALBINO, V., BERARDI, U. \& DANGELICO, R. M. (2015), "Smart Cities: Definitions, Dimensions, Performance, and Initiatives", Journal of Urban Technology, 22, 1: 3-21.

ANTHOPOULOS, L., JANSSEN M. \& WEERAKKODY, V. (2016), "A Unified Smart City Model (USCM) For Smart City Conceptualization And Benchmarking", International Journal of Electronic Government Research (IJEGR), 12, 2: 76-90.

ANTHOPOULOS, L. G. (2017a), Understanding Smart Cities: A Tool For Smart Government or An Industrial Trick?, Springer International Publishing.

ANTHOPOULOS, L. (2017b), "Smart Utopia vs. Smart Reality: Learning by Experience From 10 Smart City Cases", Cities, 63: 128-148.

BASALLA, George (2013), Teknolojinin Evrimi, (Trans. Cem Soydemir), Ankara: Doğu-Batı Yayınları.

CHEN, M., MAO, S. \& LIU, Y. (2014), "Big Data: A Survey", Mobile Netw Appl, 19: 171-209.

CHOENNI, S., BARGH, M. S., ROEPAN, C. \& MEIJER, R. F. (2016), "Privacy and Security in Smart Data Collection by Citizens", Smarter As The New Urban, Agenda A Comprehensive View Of The 21st Century City, (Eds. J. Ramon Gil-Garcia, Theresa A. Pardo \& Taewoo Nam), Switzerland: Springer International Publishing, 349366.

DESOUZA, K. C. \& JACOB B. (2017), "Big Data in The Public Sector: Lessons For Practitioners and Scholars", Administration \& Society, 49, 7: $1043-1064$.

DELOITTE (2008), "National Issues Dialogues Web 2.0: The future of collaborative government", http://www.deloitte.com/assets/DcomUnitedStates/Local\%20Assets/Documents/us_ps_web20government_March2009.PDF (Accessed: 09 September 2014).

DELOITTE (2015a), "Smart cities how rapid advances in technology are reshaping our economy and society"

https://www2.deloitte.com/content/dam/Deloitte/tr/Documents/public-sector/deloitte-nlps-smart-cities-report.pdf (Accessed: 05 May 2017).

DELOITTE (2016), "Akıllı Şehir Hartası", https://www.sehirsizin.com/Documents/Deloitte-Vodafone-Akilli-Sehir-Yol-Haritasi.pdf (Accessed: 08. May 2017).

DAMERI, R. P. (2014), "Comparing Smart and Digital City: Initiatives and Strategies in Amsterdam and Genoa Are They Digital and/or Smart?", Smart City How To Create Public And Economic Value With High Technology In Urban Space, (Eds. Renata Paola Dameri \& Camille Rosenthal-Sabroux), Switzerland: Springer International Publishing, 45-88.

DIXON, B. E. (2010), "Towards E-Government 2.0: An Assessment of Where EGovernment 2.0 Is and Where It Is Headed", Public Administration \& Management, 15, 2: 418-454.

GARDINI, S., MATTEI, M. M. \& ORELLI, R. L. (2012), "Toward A Gov 2.0 Society For All: European Strategis For Public Service Delivery", Web 2.0 Technologies And Democratic Governance: Political, Policy And Management Implications, (Eds. C. G. Reddick \& S. K. Aikins), Springer, 63-78. 
HANSEN-FLASCHEN, L. \& PARKER, K. P. (2012), "The rise of social govrnment: An advanced guide and review of social media's role in local government operations, Fels Institute of Government, University of Pennsylvania", https://www.fels.upenn.edu/news/rise-social-media-local-government. (Accessed: 18 October 2014)

HÖCHTL, J., PARYCEK, P. \& SCHÖLLHAMMER R. (2016), "Big Data in The Policy Cycle: Policy Decision Making in The Digital Era", Journal of Organizational Computing and Electronic Commerce, 26,1-2: 147-169.

KIM, G.-H., TRIMI, S. \& CHUNG, J.-H. (2014), "Big-Data Applications in The Government Sector", Communications of the ACM, 57, 3: 78-85.

KRIPPENDORFF, K. (2014), Content Analysis: An Introduction To Its Methodology, SAGE Publication.

LAVERTU, S. (2016), "We All Need Help: "Big Data" and The Mismeasure of Public Administration", Public Administration Review, 76, 6: 864-872.

MAYER-SCHÖNBERGER, V. \& CUKIER, K. (2013), Büyük Veri, Yaşama, Çalışma ve Düşünme Şeklimizi Dönüştürecek Bir Devrim, (Tran. Banu Erol), İstanbul: Paloma Yayınevi.

MERGEL, I., RETHEMEYER, R.K. \& ISETT, K. (2016), "Big Data in Public Affairs", Public Administration Review, 76, 6: 928-937.

MUNNE, R. (2016), "Big Data in The Public Sector", New Horizons For A Data-Driven Economy, (Eds. José María Cavanillas, Edward Curry \& Wolfgang Wahlster), Springer Open, 195-208.

NOVOTNÝ, R., KUCHTA, R. \& KADLEC, J. (2014), "Smart City Concept, Applications and Services", Telecommun Syst Manage, 3, 2: 1-8.

OMAR, K., STOCKDALE, R. \& SCHEEPERS, H. (2014), "Social Media Use in Local Government: An Australian Perspective", International Journal of Public Administration, 37: 10: 666-675.

PEREZ, C. C., BOLIVAR, M. P. R. \& HERNANDEZ, A. M. L. (2012), "The use of web 2.0 to transform public services delivery: The case of Spain", Web 2.0 Technologies and Democratic Governance: Political, Policy and Management Implications, (Eds. C. G. Reddick \& S. K. Aikins), Springer, 41-61.

PERLMAN, B. J. (2012), "Social Media Sites at The State And Local Levels: Operational Success and Governance Failure", State and Local Government Review, 44, 1: 67-75.

PIROG, M. A. (2014), "Data Will Drive Innovation in Public Policy and Management Research in The Next Decade", Journal of Policy Analysis and Management, 33, 2 : 537-543.

RIFKIN, J. (2015), Nesnelerin İnterneti ve İşbirliği Çağı, (Trans. Levent Göktem), İstanbul: Optimist Yayım Dağıtım.

STIMMEL, Carol L. (2016), Building Smart Cities, Baco Rotan-London-New York: CRC Press.

SCHOLL, H. J. \& ALAWADHI, S. (2016), "Creating Smart Governance: The Key To Radical ICT Overhaul at The City Of Munich", Information Polity, 21: 21-42. 


\section{Dr. Levent MEMiş}

SCHOLL, H. J. (2016), "Special Issue on "Smartness in Governance, Government, Urban Environments, and The Internet of Things": An Editorial Introduction", Information Polity, 21: 1-3.

SCHWAB, K. (2017), Dördüncü Sanayi Devrimi, İstanbul: Optimist Yayınları.

THORNE, C. \& GRIFFITHS, C. (2014), "Smart, Smarter, Smartest: Redefining Our Cities", Smart City: How to Create Public and Economic Value With High Technology in Urban Space, (Eds. Renata Paola Dameri and Camille RosenthalSabroux), Switzerland: Springer International Publishing, 89-99.

TOMAR, L., GUICHENEY, W., KYARISIIMA, H. \& ZIMANI, T. (2016), "Big Data in The Public Sector", https://publications.iadb.org/bitstream/handle/11319/7884/Big-Data-inthe-Public-Sector-Selected-Applications-and-Lessons-Learned.pdf?sequence $=1$.

(Accessed 10 October 2017).

VAROL, Ç. (2017), “Sürdürülebilir Gelişmede Akıllı Kent Yaklaşımı: Ankara'daki Belediyelerin Uygulamaları”, Çağdaş Yerel Yönetimler, 26, 1: 43-58.

VASSEUR, J.- P. \& DUNKELS, A. (2010), Interconnecting Smart Objects With Ip, Morgan Kaufmann Publishers.

VELJKOVIC, N., BOGDANOVIC-DINIC, S. \& STOIMENOV, L. (2012), "Web 2.0 as A Technological Driver Of Democratic, Transparent and Participatory Government", Web 2.0 Technologies and Democratic Governance: Political, Policy and Management Implications, (Eds. C. G. Reddick and S. K. Aikins), Springer,137-151.

WORLD ECONOMIC FORUM (2012), "Big Data, Big Impact: New Possibilities for International Development", https://www.weforum.org/reports/big-data-big-impact-newpossibilities-international-development . Accessed: 02 October 2017.

YILDIRIM, A. \& ŞIMŞEK, H. (2008), Sosyal Bilimlerde Nitel Araştirma Yöntemleri, Yedinci Baskı, Ankara: Seçkin Yayıncılık.

\section{Internet References}

Büyükşehir Akıllı Kent Sistemiyle Yönetiliyor, http://www.iha.com.tr/ankarahaberleri/buyuksehir-akilli-kent-sistemiyle-yonetiliyor-ankara-645119/ (Accessed 05 October 2017).

http://www.balikesir.bel.tr/haberler/baskan-ugur-akilli-sehirler-zirvesinde (Accessed 05 October 2017).

http://akillisehir.denizli.bel.tr/index.html (Accessed 05 October 2017).

Diyarbakır'da Akıllı Kavşak Sistemi devrede: http://www.diyarbakir.bel.tr/haberler/5218diyarbakir-da-akilli-kavsak-sistemi-devrede.html (Accessed 05 October 2017).

http://www.mersin.bel.tr/mbb-sayfa-haber-a.asp?id=8679\&yid=3\&katid=15\&baslik= (Accessed 05 October 2017).

KTP tarafından Kayseri pilot iller arasında

http://www.haberturk.com/yerel-haberler/haber/53835571-ktp-tarafindan-kayseri-pilotiller-arasinda (Accessed 06 October 2017). 
Ordu'da Akıllı Kent Oluyor: http://ordukentgazetesi.com/news_print.php?id=21197 (Accessed 05 October 2017).

Trafik Ölçüm Sistemleri, isbak.istanbul/wp-content/uploads/2016/06/07Trafik_Olcum_Sistemleri-TR.pdf (Accessed 06 October 2017).

ibb.gov.tr/tr-TR/kurumsal/Birimler/TrafikMudurlugu/.../Trafik_Faaliyet.pdf (Accessed 05 October 2017).

Akıllı Durak Uygulamaları: http://isbak.istanbul/diger-uygulamalar/akilli-durakuygulamalari/ (Accessed 06 October 2017).

Araç Takip ve Filo Yönetimi Sistemi: isbak.istanbul/wp-content/uploads/2016/06/13Ismobil-TR.pdf (Accessed 06 October 2017).

ibb.gov.tr/tr-TR/kurumsal/Birimler/TrafikMudurlugu/.../Trafik_Faaliyet.pdf Accessed 05 October 2 İçme Suyu SCADA Sistemi, https://www.isu.gov.tr/icerik/detay.aspx?ld=253 (Accessed 07 October 2017).

Akıllı Damla Sulama Sistemi, http://akillisehir.denizli.bel.tr/akillidamlasulamasistemi.html (Accessed 05 October 2017).

Akıllı Şehir, Akıllı Aydınlatma: https://www.kayseri.bel.tr/haberler/akilli-sehir-akilliaydinlatma; http://www.bursa.bel.tr/dosyalar/birimek/bursa-buyuksehir--belediyesi-akillibelediyecilik-ve-akilli-sehircilik-uygulamalari.faaliyet-ve-proje.SH9K0hU94D..pdf (Accessed 05 October 2017).

http://www.mersin.bel.tr/mbb-sayfabirim. asp? $\mathrm{id}=7927$ \&yid $=5 \& \mathrm{katid}=56$ \&altkatid $=184 \& \mathrm{bl}=\% 20$ Projeler \&baslik=Tar\%FDms al\%20Tahmin\%20ve\%20Erken\%20Uyar\%FD\%20Sistemi\%20Projesi (Accessed 07 October 2017).

Verilerle İstanbul'da toplu taşıma nasıl yönetiliyor?

http://digitalage.com.tr/verilerle-istanbulda-toplu-tasima-nasil-yonetiliyor/ (Accessed 05 October 2017).

http://isttelkom.istanbul/hizmetlerimiz/veri-merkezi-cozumleri/,

http://www.milliyet.com.tr/ibb-turkiye-nin-ilk-uluslararasi-standartta-istanbul-yerelhaber2290619/ (Accessed 07 October 2017).

Bursa Akıllı Şehir Yol Haritasında Öncü Oluyor, http://www.bursa.bel.tr/bursa--akillisehir-yol-haritasi-na-oncu-oluyor/haber/22875/ (Accessed 07 October 2017).

http://webcache.googleusercontent.com/search?q=cache:1OMuppgSCWcJ:www.bursa .bel.tr/dosyalar/birimek/bursa-buyuksehir--belediyesi-akilli-belediyecilik-ve-akillisehircilik-uygulamalari.faaliyet-ve-proje.yZAJjyoR8F..pdf $+\& c d=2 \& h l=t r \& c t=c l n k \& g l=t r$ (Accessed 05 October 2017).

Antalya çağ atlıyor, akıllı kent oluyor, https://www.antalya.bel.tr/haberler/antalya-cagatliyor-akilli-kent-oluyor (Accessed 08 October 2017). 